


\title{
Legal regulation of practices of the police as an entity in charge of preventing and combating corruption in Ukraine
}

\author{
DOI: https://doi.org/10.46398/cuestpol.3969.46
}

\author{
Lina M. Tovpyha * \\ Igor D. Pastukh ** \\ Tetiana Yu. Tarasevych *** \\ Serhii V. Bondar **** \\ Oksana V. Ilina $* * * * *$
}

\begin{abstract}
This article deals with the legal regulation of the practices of the police as an entity responsible for preventing and combating corruption. The study shows that corruption is becoming increasingly widespread, creating major obstacles to the comprehensive development of the economy and national security of any state. The objectives of this study were to clarify the problematic aspects of the legal regulation of police practices as an entity responsible for preventing corruption, to identify positive international experience in this area and to clarify its implementability in Ukraine. The corruption perceptions index regression analysis method was applied in 12 different countries around the world for 2018 and 2019. On the basis of the analysis, the authors propose to amend Ukrainian legislation with regard to the definition of the legal status of police practices as an entity responsible for preventing and combating corruption at the level of Ukrainian legislation, detailing the powers of the National Police as a specially authorized entity in the field of preventing and combating corruption in the Ukrainian Law
\end{abstract} "On the National Police".

* Lecturer, Department of Theory of State and Law, National Academy of Internal Affairs. ORCID ID: https://orcid.org/oooo-0003-0625-1188. Email: linesheane@gmail.com

** PhD in Law, Associate Professor, Head of Department of public management and administration, National Academy of Internal Affairs. ORCID ID: https://orcid.org/oooo-0002-5889-7055. Email: igordp77@gmail.com

*** PhD in Law, Head of Department of Criminal Law and Procedure, Kyiv University of Law the National Academy of Sciences of Ukraine. ORCID ID: https://orcid.org/oooo-0002-3860-9909. Email: loginova67@ukr.net

**** Researcher of Department for the Organization of Scientific Activities and Protection of Intellectual Property Rights, National Academy of Internal Affairs. ORCID ID: https://orcid.org/oooo-0oo20497-4457. Email: sergiio2021984@gmail.com

***** PhD in Law, Associate Professor of Department of Criminal Law Politics and Criminal Law, Taras Shevchenko National University of Kyiv. ORCID ID: https://orcid.org/oooo-ooo1-8933-6368. Email: 221.85.71@ukr.net 
Lina M. Tovpyha, Igor D. Pastukh, Tetiana Yu. Tarasevych, Serhii V. Bondar y Oksana V. Ilina 736

Legal regulation of practices of the police as an entity in charge of preventing and combating

Keywords: legal regulation; police practices; prevention subject; combat subject; corruption.

\section{Regulación legal de las prácticas de la policía como entidad encargada de prevenir y combatir la corrupción en Ucrania}

\section{Resumen}

Este artículo trata sobre la regulación legal de las prácticas de la policía como entidad encargada de prevenir y combatir la corrupción. El estudio muestra que la corrupción se está generalizando cada vez más, creando importantes obstáculos para el desarrollo integral de la economía y la seguridad nacional de cualquier estado. Los objetivos de este estudio fueron aclarar los aspectos problemáticos de la regulación legal de las prácticas de la policía como entidad encargada de prevenir la corrupción, identificar la experiencia internacional positiva en esta área y aclarar su implementabilidad en Ucrania. Se aplicó el método de análisis de regresión del Índice de Percepción de la Corrupción en 12 países diferentes del mundo para 2018 y 2019. Sobre la base del análisis, los autores proponen modificar la legislación de Ucrania con respecto a: la definición de la condición jurídica de las prácticas de la policía como entidad encargada de prevenir y combatir la corrupción a nivel de la legislación ucraniana; detallando los poderes de la Policía Nacional como entidad especialmente autorizada en el campo de la prevención y lucha contra la corrupción en la Ley de Ucrania «Sobre la Policía Nacional".

Palabras clave: regulación legal; prácticas policiales; sujeto de prevención; sujeto de combate; corrupción.

\section{Introduction}

Today, society needs protection from corruption more than ever (Søreide, 2019). The problem of combating corruption effectively is one of the most acute and difficult challenges (Rybak, 2011). Corruption is recognized by the world community as a threat to development as a whole (Kohler and Bowra, 2020). It largely affects the vast majority of countries and has a negative socio-economic impact (Tacconi and Williams, 2020). Corruption hinders economic growth and distorts government efforts to promote development (Lodge, 2019). 
All countries without exception are concerned about the existence and spread of a destructive phenomenon of corruption, which harms the activities of public authorities, slows down economic development and distorts the consciousness of society. As a result, each country implements its own anti-corruption program, strategy or policy (Khabarova, 2019). It is worth noting that some countries, in particular Croatia, have some achievements in this area (Norton Rose Fulbright, 2017). Progress is especially noticeable in Denmark, Poland and Lithuania.

Corruption, being one of the strong words, carries a striking power. Various ways to eradicate it - from changing the Constitution to establishing extrajudicial institutions - have not been fully successful. Corruption continues to strengthen its position (Raharjo, 2017). Combating is not easy (Holmes, 2020). There is, however, power that strengthens anti-corruption regulations in conjunction with regulations aimed at addressing this issue indirectly, such as competition supervision, financial supervision and anti-money laundering instruments. In particular, an appropriate system of law enforcement agencies has been introduced for the implementation of legal instruments to combat corruption. The police have an important place among those law enforcement agencies. Preventing and combating corruption is one of the police's functions.

At the same time, it should be noted that the spread of corruption among police officers is no exception. Of all offenses committed by police 44\% are corruption-based. Moreover, statistics from the Department of the Interior also show that more than $50 \%$ of officers who committed a crime had served less than 10 years. This further raises the issue of finding effective mechanisms to prevent and combat corruption, which primarily determines the need to develop appropriate legal support.

This issue is especially relevant for Ukraine. After all, despite the fact that corruption is a stable and objective phenomenon for many countries, in Ukraine it has reached the level that threatens the very existence of statehood. A web of corruption is, in fact, becoming a parallel system of governance, where various issues are resolved on the basis of the business interests of the most powerful oligarchs instead of being resolved by law (Durdynets et al., 2020). At the same time, Ukraine's integration into the world economy forces it to adhere to international standards and rules (Lutsenko, 2019). Overcoming the phenomenon of corruption is an integral condition of our country's European integration policy.

In accordance with the above issues, the research objective is to clarify the problematic aspects of the legal regulation of practices of the police as an entity in charge of preventing and combating corruption, identify positive foreign experience in this area and ascertain its implementability in Ukraine. Fulfilling these objectives will allow making proposals to improve the quality of legal regulation of the said public relations, as well as identifying shortcomings of the police powers execution in this area. 
Lina M. Tovpyha, Igor D. Pastukh, Tetiana Yu. Tarasevych, Serhii V. Bondar y Oksana V. Ilina 738

Legal regulation of practices of the police as an entity in charge of preventing and combating

The scope of the article is to improve the legal regulation of practices of the police as an entity in charge of preventing and combating corruption.

\section{Literature review}

The public danger of corruption is too high. It is well known that corruption threatens the rule of law, democracy, and human rights, undermines the foundations of good governance, violates the principles of equality and social justice, distorts competition, hinders economic development, threatens the stability of democratic institutions and public morals (Lobazova, 2019).

The EU citizens recognize the gravity of corruption as a social and political pathology: $72 \%$ of EU residents agree that corruption is a serious problem in their country. More than 9 out of 10 Greek (94\%), Czech (93\%), Hungarian (93\%), Portuguese (91\%) and Slovenian (91\%) citizens share this concern about corruption. Similarly, $88 \%$ of Poles agree that corruption is a serious problem, while $76 \%$ believe that preventing and combating international corruption will be more effective if it is adopted at the system level of the European Union rather than at the level of independent states (Gadowska, 2010).

Transparency International's largest Global Corruption Barometer survey, with about 114,000 respondents in 107 countries, confirms that bribery is a serious global problem. Moreover, one in four respondents reported paying a bribe in the last twelve months. At the same time, most respondents consider their governments' efforts in combating the problem ineffective, and in most countries citizens report that there are now more cases of corruption than before (Edelman, 2016).

The situation has worsened in recent years, which has been reflected in the deterioration of the Corruption Perceptions Index (Siddiquee and Zafarullah, 2020). Corruption has become a systemic problem that harms the most resilient public institutions, forcing the government to stop fulfilling its obligations to society and to fulfil only paid obligations to various influence groups and elites. This situation rejects and hinders the transparency of the state machinery, the decision-making process, the predictability of the investment climate and economic development. In turn, this leads to inevitable economic and social losses (Durdynets et al., 2020).

The main causes of corruption are: lack of any anti-corruption policy and awareness of the importance of such issues as professional ethics, conflict of interest; low wages in certain social spheres, high corporatism, especially in the police (Truntsevskiy and Olliv'en, 2017). 
Researchers identify several models of institutional prevention and combating corruption in the world. At the same time, it should be noted that the positions of foreign and Ukrainian scholars on this issue differ. While foreign scholars distinguish three models, Ukrainian researchers decide on only two. Ukrainian scholars identify two fundamentally different options for building anti-corruption mechanism:

1) Separation of an entity outside the law enforcement system, which is responsible for the development, implementation of anti-corruption policy and its coordination with anti-corruption strategies. The latter were dictated by international requirements for combating and preventing corruption (Lithuania, Latvia);

2) Assignment of these functions to law enforcement agencies (Romania) (Halkina, 2019).

Foreign scholars attribute the establishment of a large number of various anti-corruption bodies (Germany) to the first model, while the inclusion of combating corruption in the competence of law enforcement bodies (Romania), the creation of a single specially authorized anti-corruption body (Lithuania, Latvia) - to the second one (Kanan, 2019).

One of the entities in charge of preventing and combating corruption in Ukraine is the National Police. Stable and effective functioning of the National Police of Ukraine, as one of the entities in charge of combating corruption, is a necessary condition for the protection of the constitutionalism, law and order, respect for human and civil rights and freedoms, and the effectiveness of the police stability of social development. Successful realization of national interests and social development stability largely depend on the effectiveness of the policing practices (Titunina and Kirilenko, 2017).

In order to ensure the protection of human rights and freedoms, the National Police diverts its efforts to counteract this phenomenon both in the internal organizational activities of the central governing body of the National Police, in territorial bodies, enterprises, institutions and organizations belonging to its sphere of administration, and outside this area (Shatrava, 2016).

In order to reduce the crime rate and create an effective prevention system in the context of reforming the law enforcement system, it is necessary, first of all, to create an effective legal framework in this area, as well as improve existing forms, methods and measures of preventive activities, in particular, the police (Kovalenko, 2016). The legal status of the police as an entity in charge of preventing and combating corruption remains unclear at the level of national legislation, which determines the legal background for both anti-corruption activities and policing practices in general. 
Lina M. Tovpyha, Igor D. Pastukh, Tetiana Yu. Tarasevych, Serhii V. Bondar y Oksana V. Ilina 740

Legal regulation of practices of the police as an entity in charge of preventing and combating

The problem of inadequate and imperfect legal regulation of practices of the police as a subject of preventing and combating corruption through the Law of Ukraine "On the National Police of Ukraine" is worth noting. In particular, in terms of clearly determining the powers at the legislative level of each entity specially authorized for combating corruption in Ukraine in accordance with assigned functions (Zhukovska, 2018).

Interaction between anti-corruption bodies in Ukraine remains insufficiently regulated, which complicates the implementation of anticorruption policy. In particular, these problems are due to insufficient regulation of the activities of new bodies (Muliar and Khovpun, 2019).

We cannot disregard inadequate planning of investigations, inadequate use of electronic surveillance, inability to question key witnesses, breaches of confidentiality and lack of timeliness. Undoubtedly, the problem is now smaller than in the past, thanks to, for example, widespread introduction of more effective verification practices, better education, greater use of modern covert investigations, much more competent and dedicated internal investigators and professionalization in general. However, the problem has not disappeared in any case (Miller, 2014).

Besides, the fact that the police are one of the entities in charge of combating corruption does not mean that corruption cannot exist among the police. Despite the general increase in trust in the police and their staff, public opinion polls over the past few years suggest that anti-corruption efforts today need to be not only external, but also internal (within the police units). It is obvious that corrupt law enforcement agencies are not able to perform their tasks effectively, and this quickly poses a real threat to the state, society and the individual (Pechegin and Prokhorova, 2017).

Accordingly, the education system, and the police officer training system in our case, is the most important social institution in combating corruption. The younger generation has weakness associated with the development of anti-corruption culture itself, so we can conclude that anticorruption education is needed for the younger generation to help them form a legal consciousness to behave in line with anti-corruption provisions (Sabila, 2020).

Professional education is the most important part of modern education, as it forms the future specialist's need to take into account not only personal but also public and state interests. The existing anti-corruption legislative framework does not allow to overcome the manifestations of corruption without a set of activities, which include the implementation of a psychological program of building anti-corruption culture (Klymenko, 2019).

In addition, reducing the incentives and opportunities for corruption in the police is possible by improving their low wages and miserable working 
conditions, as well as the public punishment of corrupt police officers (Quah, 2019).

The most effective approach to organizational and legal support of combating corruption is one that includes criminal prosecution, transparency of information about civil servants and individuals, as well as the interaction of law enforcement agencies with fiscal authorities to identify sources and flows of illegal support. All this requires the active participation of civil society institutions, as only the public is able to ensure the necessary level of transparency in the implementation of anti-corruption practices (Durdynets et al., 2020). Anti-corruption activists, which include NGOs, public organizations, student activists, and social media are important in this area.

Openness of the power entities, moral and psychological rejection of corruption by citizens, strengthening transparency and promoting the involvement of the population in the implementation of anti-corruption activities, that is a number of ethical (for employees) and moral (for society) principles that prevent citizens from committing acts of corruption, cause a decrease in corruption rates (Khabarova, 2019).

Only a comprehensive approach to tackling corruption will eradicate negative trends and manifestations. It is reasonable to solve the problems that have arisen both at the level of legislation, and at the level of organization of law enforcement activities. Special attention should be paid to the education and personality development of future law enforcement officers (Sebeleva, 2020).

Review of Ukrainian and foreign literature shows that scholars have limited coverage of the legal regulation of practices of the police as an entity in charge with preventing and combating corruption. In particular, researchers focus mainly on the aspect of preventing and combating corruption in general.

\section{Methods and materials}

Most research on preventing and combating involved methods of statistical processing of the results. Statistical research allows revealing the picture of corruption indicators in Ukraine and the world. More effective models for preventing and combating corruption can be found by comparing statistics from different countries and years.

Our research involved the method of regression analysis. In the first stage of the study, we built statistical distributions through the method of regression analysis and developed two charts of Corruption Perception Index (CPI) in different countries based on the data obtained using the 
Lina M. Tovpyha, Igor D. Pastukh, Tetiana Yu. Tarasevych, Serhii V. Bondar y Oksana V. Ilina 742

Legal regulation of practices of the police as an entity in charge of preventing and combating

dialectical method, which reflected the number of points for 2018 (Figure 1) and 2019 (Figure 2). In particular, we selected statistics on the CPI of 12 countries, including Ukraine, from a list of 180 countries providing published data of the global ranking of corruption indices of Transparency International for 2018 and 2019. Subsequently, the selected data were analysed and displayed by placing on charts in alphabetical order by country name for further comparison. The comparison revealed some differences in the ratings with the same list of countries but different years. In the second stage of the study, the countries selected for comparison were grouped according to the anti-corruption model and shown in Table 1. In the third stage of the study, conclusions were drawn based on the obtained data using the observation method, which later became the basis for the proposals.

Corruption Perceptions Index (CPI) is an indicator that has been calculated by Transparency International since 1995. The organization itself does not conduct its own surveys. The index is calculated on the basis of 13 studies of reputable international institutions and research centres. Ukraine's figures we calculated on the basis of 9 sources. The Corruption Perceptions Index is based on independent research and surveys involving international financial and human rights experts, including the World Bank, Freedom House, the World Economic Forum, the Asian and African Development Banks, etc.

Unit of measurement is a point. The key indicator of the Index is the number of points, not the place in the ranking. The minimum score (o points) means that corruption actually replaces the state, the maximum (100 points) indicates that there is almost no corruption in society.

\section{Results and discussion}

As initial descriptive evidence, Figure 1 and Figure 2 show that the Corruption Perception Index varies from country to country. In particular, this is illustrated by the example of 12 countries such as: Bulgaria, Armenia, Denmark, Latvia, Lithuania, Germany, Poland, Russia, Romania, Slovakia, Hungary, Ukraine. At the same time, the picture of the Corruption Perceptions Index in the same countries for different years also differs, although not significantly. The results obtained are shown in Figure 1 and Figure 2.

The source data for comparison were taken from Transparency International's Global Corruption Index for 2018 and 2019.

30 points out of 100 possible is the result of the 2019 Corruption Perceptions Index for Ukraine. In 2018, the indicators were equal to 32 
points. This indicates that the situation with preventing and combating corruption in Ukraine has deteriorated compared to 2018.

Russia is next to Ukraine in the ranking. However, the indicators of the Corruption Perceptions Index in Russia have remained unchanged. Among its neighbours, Ukraine is ahead of Russia, which has maintained its position ( 28 points). Poland ( 58 points) and Slovakia (50 points) are in the lead among the neighbours. While Poland has minus 2 points, Slovakia is stable in its indicators compared to 2018. We also see a slight decrease in the index in Denmark - minus 1 point, Latvia, Hungary and Poland - minus 2. At the same time, CPI leaders have not changed significantly. Denmark and Germany rank first with 87 and 80 points, respectively. Bulgaria and Lithuania scored +1 in the ranking. At the same time, Armenia added the most points $(+7)$ (42 in total) compared to the previous year.

Figure 1. Corruption Perceptions Index 2018

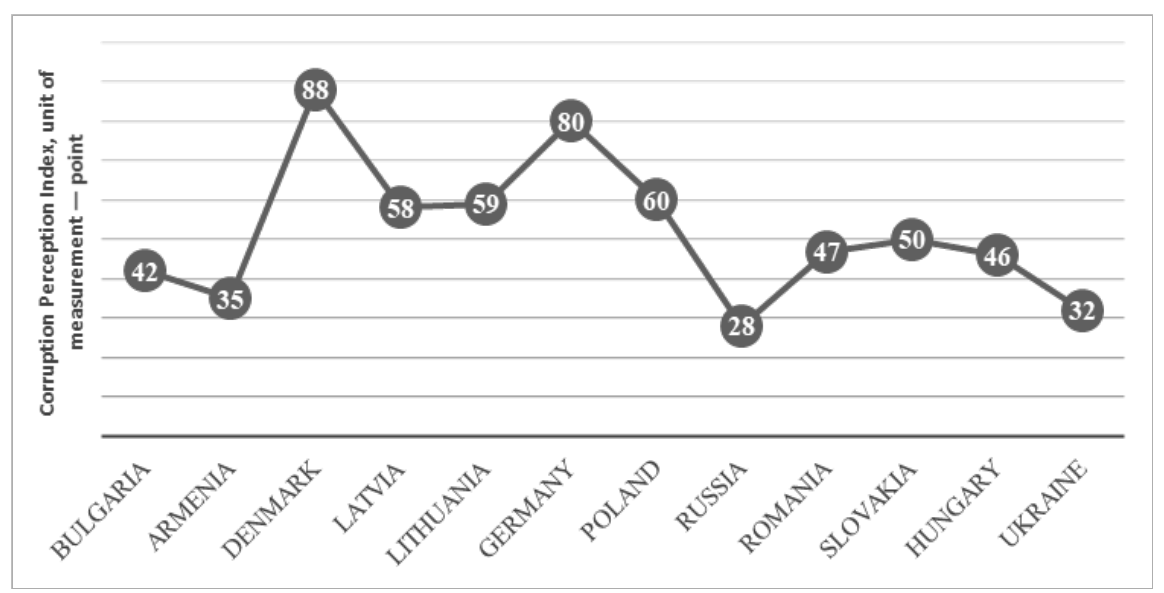

Source: Transparency International Ukraine (2018). 
Lina M. Tovpyha, Igor D. Pastukh, Tetiana Yu. Tarasevych, Serhii V. Bondar y Oksana V. Ilina Legal regulation of practices of the police as an entity in charge of preventing and combating

Figure 2. Corruption Perceptions Index for 2019

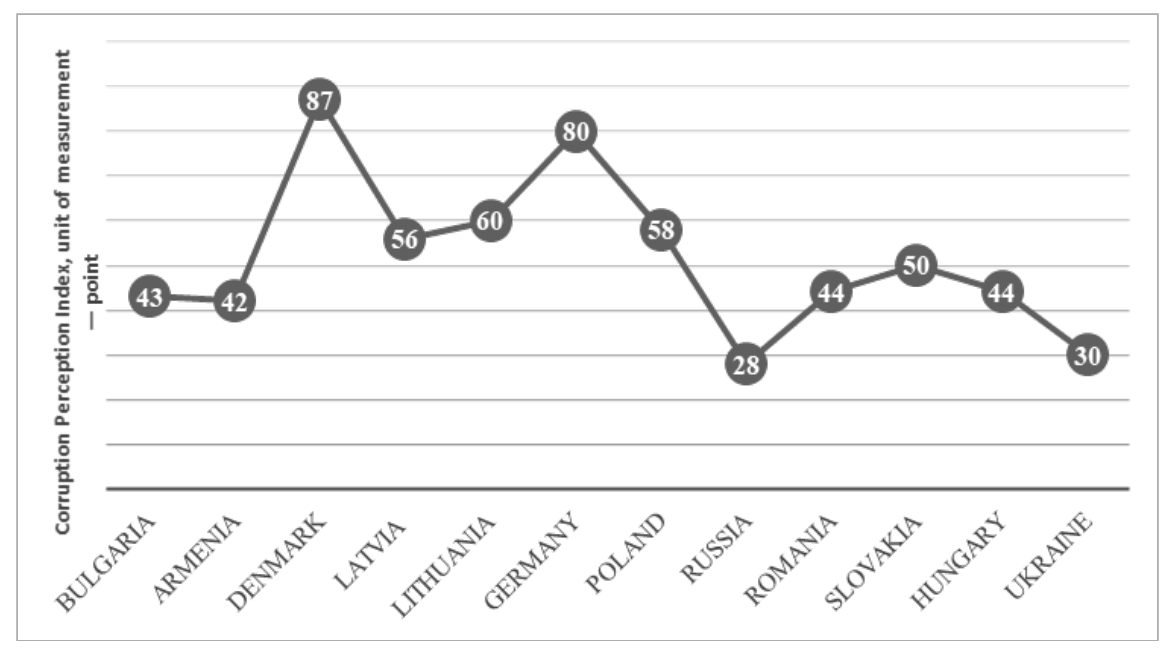

Source: Transparency International Ukraine (2019)

The charts above show that some countries are severely affected by corruption, while others are less affected by it, but none is impervious to the problem.

At the same time, according to the anti-corruption models (Kanan, 2019), the countries can be grouped as follows on the Table 1 .

Table 1. The types of anti-corruption models and the countries that use them

\begin{tabular}{|l|l|}
\hline Model & Country \\
\hline $\begin{array}{l}\text { 1. The function of combating corruption } \\
\text { is entrusted to a large number of various } \\
\text { anti-corruption bodies }\end{array}$ & $\begin{array}{l}\text { Germany, Ukraine, Poland, } \\
\text { Slovakia }\end{array}$ \\
\hline $\begin{array}{l}\text { 2. There is a separate entity outside the } \\
\text { law enforcement system }\end{array}$ & $\begin{array}{l}\text { Lithuania, Latvia, Armenia, } \\
\text { the Russian Federation }\end{array}$ \\
\hline $\begin{array}{l}\text { 3. Anti-corruption is attributed to the } \\
\text { competence of the law enforcement body }\end{array}$ & $\begin{array}{l}\text { Romania, Hungary, Bulgaria, } \\
\text { Denmark }\end{array}$ \\
\hline
\end{tabular}


The considered results allow assuming that the model where the anti-corruption function is entrusted to a large number of various anticorruption bodies is the most effective in terms of combating corruption. After all, while Lithuania and Latvia have a separate entity outside the law enforcement system, which is responsible for the development, implementation of anti-corruption policy and its coordination with anti-corruption strategies, Germany created a large number of various anti-corruption bodies, in Romania anti-corruption is attributed to the competence of the law enforcement agency. At the same time, in Latvia the indicators of the Corruption Perception Index in 2019 decreased by only two points compared to 2018, in Lithuania - increased by one point, in Germany - remained unchanged, in Romania the indicators decreased by three points. Leading countries in the fight against corruption have institutions to combat corruption of all types, but there are also countries that do not have specialized bodies to combat this phenomenon. However, in Ukraine, which has various anti-corruption bodies as Germany, the situation is getting worse, as the Corruption Perception Index fell by two points. At the same time, the general nature of the indicator does not allow recording various manifestations of corruption and give detailed advice on how to combat this phenomenon. Thus, one cannot speak of the advantages of one type of specialized anti-corruption institution over others.

As for Ukraine, in our opinion, this situation is due to the fact that today a number of legal and organizational tasks of the police as one of the subjects of anti-corruption remain unresolved in Ukraine. In particular, the powers of the police are regulated by Section IV of the Law of Ukraine No. 580-VIII "On the National Police" dated July 2, 2015 (Verkhovna Rada of Ukraine, 2015). The first part of Article 23 of this Law, which includes 28 paragraphs, determines the main powers of the police in accordance with functions assigned. They include: preventive activities aimed at preventing offenses (paragraph 1); pre-trial investigation of criminal offenses within the relevant jurisdiction (paragraph 6); in cases provided by law - proceedings in cases of administrative offenses, making decisions on the penalties under administrative law and ensuring their enforcement (paragraph 8), etc.

Given the above, we can state that the powers listed above are general in nature. Of course, when it comes to preventing offenses, offenses are interpreted as both corruption and corruption-related offenses. Pretrial investigation of criminal offenses within the relevant jurisdiction also provides for investigation into corruption offenses. Accordingly, administrative proceedings include corruption-related administrative proceedings.

Thus, no specific powers of the National Police as a specially authorized anti-corruption entity are established at the legislative level, the Law of Ukraine "On the National Police" does not determine the units that can be assigned special anti-corruption powers (Zhukovska, 2018). 
Lina M. Tovpyha, Igor D. Pastukh, Tetiana Yu. Tarasevych, Serhii V. Bondar y Oksana V. Ilina 746

Legal regulation of practices of the police as an entity in charge of preventing and combating

The legal status of the police as an entity in charge of preventing and combating corruption should be clarified at the level of national legislation, which provides the legal framework for both anti-corruption activities and policing practices in general. In particular, the provisions of the Law of Ukraine "On Prevention of Corruption" (Verkhovna Rada of Ukraine, 2014) should define the police as a specially authorized entity in charge of preventing and combating corruption (Section 1 of Article 1). In turn, the provisions of the Law of Ukraine "On the National Police" shall have broader definition of the police's function to combat crime as the task of preventing and combating crime.

A significant gap relates to the lack of an established mechanism for protecting those who disclosed or reported information about corrupt practices of officials. Article 53 of the Law of Ukraine "On Prevention of Corruption" stipulates for state protection of persons providing assistance in preventing and combating corruption. But in practice, the Law of Ukraine "On Ensuring Security of the Persons who Participate in Criminal Legal Proceedings", which provides for the state protection of those who help in combating corruption is implemented at a rather low level. First of all, this is due to financial problems and the workload of law enforcement agencies. Therefore, the mechanism of protection of persons who disclose information about corruption offenses needs both legislative and organizational improvement (Luhovyi, 2019).

In order to effectively fulfil the main crime prevention tasks and functions of the police, it is necessary not only to improve the legal framework of practices of the police in accordance with international standards, but also to increase the efficiency of the National Police of Ukraine. It is necessary to look for qualitatively new approaches to the implementation of preventive activities that will correspond to the realities of today, and take into account current trends in society and the state. The performance of crime prevention functions by police units depends not only on a clear legal definition of the functions, rights and responsibilities of each structural unit, but also on their actual implementation in practice, as well as the coordination of actions of these entities in prevention activities. The work of all police units to prevent crime should be coordinated both internally (coordination of actions of the National Police of Ukraine), and externally (police units must coordinate their actions with other government agencies, NGOs, individual citizens engaged in preventive activities) (Kovalenko, 2016).

The key to successful performance of the task of minimizing the manifestations of corruption is to ensure the appropriate level of knowledge of anti-corruption legislation as representatives of public administration and society as a whole. On the one hand, it contributes to the effective operation of statutory preventive anti-corruption mechanisms, and, on the other - increases the level of legal awareness of citizens, which reduces the 
risk of violation of their fundamental rights and freedoms in everyday life, and also contributes to the formation of intolerance of the population to the manifestations of corruption (Shatrava, 2016). In particular, training of officials, especially those in direct contact with perpetrators (police officers in this case), is an important component of preventing corruption (Truntsevskiy and Olliv'en, 2017).

In addition, the problem of corruption in the police themselves needs to be addressed. Corruption in the police is a widespread serious problem for many reasons. One is that the police, as opposed to other civil servants, are often armed and can therefore pose a physical threat to citizens. Second, citizens usually expect the police to support the law and become the "last destination" in combating crime, including with other government officials: if there is no trust in law enforcement officers, most citizens have nowhere else to go in search of justice (Holmes, 2020).

The anti-corruption culture development in future police officers, taking into account the anti-corruption component, should be a purposeful process of training and education for the benefit of both society and the individual, which provides for achieving the following objectives: acquaintance with corruption and its manifestations in various spheres of life, their causes and consequences; development of the basics of legal culture and skills of adequate analysis and personal assessment of this social phenomenon; teaching cadets that corruption is multifaceted, it is associated not only with illegal actions in the field of economic and political relations, but also is a specific element of culture and consciousness of society; give knowledge that provides behaviour complying with legal and moral and ethical norms in corrupt genic situations; overcoming legal nihilism; stimulating motivation for anti-corruption behaviour; formation of a clear and consistent attitude to corruption, active negative attitude to this phenomenon; formation of behavioural mechanisms to combat corruption, etc. Thus, anti-corruption culture development programs should be systemic, and should include anti-corruption components, which will be aimed at developing cadets' anti-corruption worldview, raising the level of their legal awareness and legal culture (Klymenko, 2019).

It is advisable to use anti-corruption education at different stages of professional activity with the use of a comprehensive approach to the formation of anti-corruption behaviour, which allows the use of various forms of training of police officers. After all, it is a comprehensive approach that allows paying attention to the needs and difficulties in the field of corruption prevention in the learning process, without spending time for basic educational information (Mironkina, 2020). It is necessary to take into account the anti-corruption component in professional training of future police officers as a set of these components of the individual's anti-corruption culture: cognitive, emotional-motivational, behavioural (Klymenko, 2019). 
Lina M. Tovpyha, Igor D. Pastukh, Tetiana Yu. Tarasevych, Serhii V. Bondar y Oksana V. Ilina 748

Legal regulation of practices of the police as an entity in charge of preventing and combating

The experience of foreign countries in the studied field also deserves attention, in particular, the experience of countries with the best indicators of the Corruption Perceptions Index. Currently, we can benefit from more than 10 years of experience in other European countries (Hac, 2016). The anti-corruption strategy at the national level in Lithuania shows progress over the last ten years (Norton Rose Fulbright, 2017).

An effective system for preventing corruption offenses in the German police is based on detailed legal regulation at both the federal and state levels, and includes not only organizational but also social measures (Pechegin and Prokhorova, 2017). Germany also provides quite fruitful cooperation between fiscal and law enforcement agencies in combating corruption, where the concept of "unfair enrichment", which is widely used in tax and civil law, is enshrined in law (Huzovatyi, 2016).

Expanding the system of combating corruption crimes in the field of regulatory impact of tax legislation significantly increases the ability of law enforcement agencies to track the origin and legality of the use of income and financial resources of citizens. The instruments of fiscal authorities not only expand the possibilities of supervision and monitoring of criminal investigation bodies, but also perform a preventive function, as this significantly complicates the commission of the relevant type of crime (Durdynets et al., 2020).

The Polish police have developed anti-corruption solutions that, as an institution and, indirectly, as the environment of police officers, have gone through many different stages, reaching the current state of affairs (Hac, 2016).

The policy of preventing and combating corruption in Poland implements a wide range of disciplinary and criminal measures (strengthening criminal and administrative legislation to combat corruption; establishment of specialized institutions; establishment of special mechanisms of external and internal control over public administration; effective judicial system), preventive (mechanisms that facilitate various procedures, where the subjects are citizens on the one part and public authorities on the other; elimination of gaps in legislation that gave way to corruption abuse; clear detailed codes of conduct for public officials and specific steps to act in certain situations; providing access to public information and e-government; instruction of the population and officials; support for non-governmental organizations, etc.). Taken together, all these measures yield adequate results, which allows eradicating corruption from the public sector in Poland year to year, and brings the country closer to states with a minimum level of corruption (Rybak, 2011).

Using a unique survey of Polish central government civil servants, it was found that, where applied in practice, disciplinary and ethical codes 
reinforce each other in order to restrain bribery as a form of corruption in the civil service. Anti-corruption activities are the most effective when managers have several consistently implemented tools (Meyer-Sahling and Mikkelsen, 2020).

Analysing the experience of Denmark, we can conclude that the corruption prevention activities implemented in European countries coincide with the anti-corruption measures applied in Ukraine for the most part. Those activities include, in particular: adoption of anti-corruption legislation, ratification of international treaties, introduction of public control, establishment of stricter responsibility for committing acts of corruption, etc. However, there is a certain feature that reduces the corruption level - it is the openness of the authorities, moral and psychological rejection of corruption by citizens, increasing transparency and promoting public involvement in anti-corruption activities. That is, a number of ethical (for employees) and moral (for the whole society) principles are applied that do not allow citizens to commit acts of corruption. On this basis, we can also conclude that one of the priority principles that can reduce the corruption level is the moral and ethical education of citizens - this is what Ukraine should actually strive for (Khabarova, 2019).

To combat offenses in the public institutions, methods selected in such a way as to be both preventive (including by raising awareness of the dangers and avoiding situations of corruption) among employees, and to act as a deterrent to potential offenders, should be used. Focusing on just one of these areas will not be that much effective. Over the last decade, a littleknown but noteworthy method of combating offences in public institutions has been adopted and remains in use in Europe, including in the countries of the so-called post-Soviet bloc. This is called integrity testing - a solution that was initially widely used by public safety groups in the Anglo-Saxon countries and the United States and has been successfully implemented in some countries on our continent (Hac, 2016).

Methods that can significantly reduce corruption also include reducing discretionary decision-making, radical restructuring, risk assessment, greater use of psychological testing, improved working conditions, lifestyle monitoring, the creation of anti-corruption agencies that are completely independent of the police (Holmes, 2020).

In connection with the emergence and large-scale development of information systems and technologies, humanity has got a new way of life - information, which has become increasingly important and integral phenomenon of the world. The opportunities of informational impact on people has increased enormously, making higher adaptive requirements to them and society as a whole. The modern world is characterized by the rapid development of information technology (Yakhontova and Yakhontov, 2020). Therefore, it would be reasonable to introduce active media 
Lina M. Tovpyha, Igor D. Pastukh, Tetiana Yu. Tarasevych, Serhii V. Bondar y Oksana V. Ilina 750

Legal regulation of practices of the police as an entity in charge of preventing and combating

monitoring. After all, given the insecurity of those who make information about corruption offenses public, we should not expect a significant increase in the number of reports.

In general, a systemic approach must also be introduced for the effective implementation of anti-corruption policy in Ukraine. After all, the phenomenon of corruption is systemic, and, accordingly, it can be overcome only by joint efforts. Prevention of corruption, as a strategic direction of state policy, should be carried out in a combination of targeted actions of persons authorized to perform state functions within the implementation of a single state anti-corruption system (Boboshko, 2018). Only effective cooperation may help to restore human rights and freedoms, the state in criminal proceedings, and bring the perpetrators to justice (Muliar and Khovpun, 2019). After all, although there are several different law enforcement agencies in different countries authorized to prevent corruption, the lack of coordination between them makes their total value less than the value of the parts. For the most part, law enforcement agencies with narrow powers to detect and act on issues other than corruption rarely exercise their potential in practice when it comes to combating the symptoms of corruption, as their law enforcement actions are not enough coordinated (Søreide, 2019).

\section{Conclusions}

Based on the above, we can conclude that it is appropriate to clarify the legal status of the police as an entity in charge of preventing and combating corruption at the level of national legislation, which provides the legal framework for both anti-corruption activities and policing practices in general.

In addition, the powers of the National Police as a specially authorized entity in the field of preventing and combating corruption provided in the Law of Ukraine "On the National Police" need to be specified in detail. It is advisable to identify the units that may be entrusted with special powers in the field of preventing and combating corruption.

The gap related to the lack of an established mechanism to protect those persons who have disclosed or reported information about corrupt practices of officials needs to be addressed at the legislative level.

The legal regulation of practices of the police as an entity in charge of preventing and combating corruption is not perfect both in Ukraine and in the world. However, the experience in regulating the practices of the police as an entity in charge of preventing and combating corruption in some European countries undoubtedly shows some progress in comparison with Ukraine. 
Ukraine is currently not entirely on the right track. Therefore, it would be appropriate to make appropriate changes to the legislation of Ukraine, considering foreign experience in this area. Regarding the cooperation of the police with other law enforcement agencies, with the public, education and training of police officers, their public awareness activities. At the same time, we must not forget that there is no universal model in the world that would meet all the necessary criteria for our state.

It is necessary to look for qualitatively new approaches to the preventive activities that will correspond to the realities of today and take into account current trends in society and the state.

Finally, it should be noted that the issue of legal regulation of practices of the police as a subject of preventing and combating corruption requires further research. Given the current situation in Ukraine, it is advisable to consider the experience of anti-corruption activities of the police of countries with ongoing armed conflicts.

\section{Bibliographic References}

BOBOSHKO, Olena. 2018. "The mechanism of activity of law enforcement, courts in pre-trial investigation of criminal corruption offenses" In: Lex Portus. Vol. 1, pp. 153-164.

DURDYNETS, Myroslav; PERELYHINA, Raisa; KLYMENKO, Olga; SEMENIUK, Iryna; KOSTETSKA, Lidiia. 2020. "Counteraction to corruption offences in Ukraine and the EU: Comparative legal aspect" In: Academic Journal of Interdisciplinary Studies. Vol. 9, No. 5, pp. 227239.

EDELMAN. 2016. Edelman Trust Barometer. Available online. In: http:// www.edelman.com/insights/intellectual-property/2016-edelman-trustbarometer. Consultation date: 23/12/2020.

GADOWSKA, Kaja. 2010. "National and international anti-corruption efforts: the case of Poland" In: Global Crime. Vol. 11, No. 2, pp. 178-209.

HAC, Piotr. 2016. "Integrity Testing in Poland - Issues, Experience and Practical Comments” In: Internal Security. Vol. 8, No. 2, pp. 67-84.

HALKINA, Olena. 2019. Some issues of organizing the activities of law enforcement agencies in Europe in the field of anti-corruption. Specific Features of Implementing Anticorruption Legislation: from Investigation to Decreed, pp. 208-210. Kharkiv, Ukraine. 
Lina M. Tovpyha, Igor D. Pastukh, Tetiana Yu. Tarasevych, Serhii V. Bondar y Oksana V. Ilina 752 Legal regulation of practices of the police as an entity in charge of preventing and combating

HOLMES, Leslie. 2020. Police corruption. Oxford Research Encyclopedia of Criminology and Criminal Justice. Oxford, UK.

HUZOVATYI, Oleksiy. 2016. Criminal liability for illegal enrichment (comparative study). PhD dissertation. Dnipropetrovsk State University of Internal Affairs. Dnipro, Ukraine.

KANAN, Ayoub. 2019. "The innovative models of functioning of anti-corruption bodies in the world" In: Public Administration Aspects. Vol. 7, No. 11, pp. $79-84$.

KHABAROVA, Tetiana. 2019. "Foreign experience of prevention corruption" In: The Journal of V.N. Karazin Kharkiv National University. Series: "Law". Vol. 27, pp. 71-77.

KLYMENKO, Ihor. 2019. "Anti-corruption components of police training" In: Teoria i praktyka suchasnoi psykhologii. Vol. 6, No. 2, pp. 198-203.

KOHLER, Jillian; BOWRA, Andrea. 2020. "Exploring anti-corruption, transparency, and accountability in the World Health Organization, the United Nations Development Programme, the World Bank Group, and the Global Fund to Fight AIDS, Tuberculosis and Malaria" In: Globalization and Health. Vol. 16, pp. 101-118.

KOVALENKO, Andriy. 2016. "Police as the subject of crime prevention" In: Naukovyi visnyk Mizhnarodnoho humanitarnoho universytetu. Seria: Yurysprudentsiia. Vol. 24, pp. 110-113.

LOBAZOVA, Olga. 2019. "Mentality as a factor of innovation and anti-corruption behavior in the social management system" In: International Journal of Innovative Technology and Exploring Engineering Regular Issue. Vol. 8, No. 12, pp. 4667-4672.

LODGE, Tom. 2019. Corruption in African politics. Oxford Research Encyclopedia of Politics. Oxford, UK.

LUHOVYI, Volodymyr. 2019. "Ways to improve administrative legal mechanism preventing anti-corruption offenses, what the police do" In: Scientific Journal of Public and Private Law. Vol. 1, No. 2, pp. 44-50.

LUTSENKO, Olena. 2019. “Anticorruption compliance:International experience in legal regulation and innovation for Ukraine" In: Humanities \& Social Sciences Reviews. Vol. 7, No. 5, pp. 765-770.

MEYER-SAHLING, Jan.-Hinrik; MIKKELSEN, Kim. 2020. "Codes of ethics, disciplinary codes, and the effectiveness of anti-corruption frameworks: Evidence from a survey of civil servants in Poland” In: Review of Public 
Personnel Administration. Available online. In: https://journals. sagepub.com/doi/10.1177/0734371X20949420. Consultation date: o6/12/2020.

MILLER, Seumas. 2014. "Human rights, police corruption and anti-corruption systems for police organisations" In: Australian Journal of Human Rights. Vol. 20, No. 2, pp. 165-180.

MIRONKINA, Oksana. 2020. "A comprehensive approach to the formation of anti-corruption behaviour of the internal affairs bodies employees in the professional development system" In: Vestnik of the St. Petersburg University of the Ministry of Internal Affairs of Russia. Vol. 3, No. 87, pp. 210-217.

MULIAR, Galina; KHOVPUN, Oleksiy. 2019. "Interaction of anticorruption agencies in Ukraine during the investigation of criminal proceedings" In: Visnyk Akademii pratsi, sotsialnykh vidnosyn i turyzmu. Vol. 2, pp. 5665 .

NORTON ROSE FULBRIGHT. 2017. Countries Curbing Corruption: Research from comparing 41 national anti-corruption strategies Insights and guidance for leaders. Available online. In: http://www. nortonrosefulbright.com/knowledge/publications/147479/countriescurbing-corruption. Consultation date: 06/12/2020.

PECHEGIN, Denys; PROKHOROVA, Evgenia. 2017. "Anti-corruption in police bodies of the Russian Federation and the Federal Republic of Germany" In: Journal of Foreign Legislation and Comparative Law. Vol. 5, No. 66, pp. 122-128.

QUAH, Jon. 2019. "Combating police corruption in Indonesia: Cleansing the buaya (crocodile)" In: Asian Education and Development Studies. Vol. 9, No. 2, pp. 129-143.

RAHARJO, Agus. 2017. "Anti-corruption special detachment, is it necessary?" In: Jurnal Dinamika Hukum. Vol. 17, No. 3.

RYBAK, Andriy. 2011. "State anti-corruption policy in Poland: regulatory and institutional aspect” In: Gilea: naukovyi visnyk. Vol. 50, pp. 717-725.

SABILA, Helsa. 2020. "Improve young generation awareness for behavior anticorruption through anticorruption education" In: SSRN Electronic Journal. Available online. In: https://papers.ssrn.com/sol3/papers. cfm?abstract_id=3625359. Consultation date: 06/12/2020.

SEBELEVA, Julia; NIKITIN, Evgeniy. 2020. "On improving the legal regulation of anti-corruption activity of the police” In: A Breakthrough in Science: 
Lina M. Tovpyha, Igor D. Pastukh, Tetiana Yu. Tarasevych, Serhii V. Bondar y Oksana V. Ilina Legal regulation of practices of the police as an entity in charge of preventing and combating
corruption in Ukraine

Development Strategies. Available online. In: https://interactiveplus.ru/ru/article/541224/discussion_platform. Consultation date: o6/12/2020.

SHATRAVA, Serhiy. 2016. "Location and features of functioning the National Police of Ukraine in the subjects of counteraction to corruption system" In: Visegrad Journal on Human Rights. Vol. 4, No. 1, pp. 222-226.

SIDDIQUEE, Noore Alam; ZAFARULLAH, Habib. 2020. "Absolute power, absolute venality: The politics of corruption and anti-corruption in Malaysia” In: Public Integrity. pp. 1-17.

SØREIDE, Tina. 2019. "Regulating corruption in international markets: Why Governments introduce laws they fail to enforce." Eric Brousseau; Jean-Michel Glachant; Jerome Sgard (Eds.), In: The Oxford Handbook of Institutions of International Economic Governance and Market Regulation. Available online. In: https://www.oxfordhandbooks. com/view/10.1093/oxfordhb/9780190900571.001.0001/oxfordhb9780190900571-e-31. Consultation date: 06/12/2020.

TACCONI, Luca; WILLIAMS, David. 2020. "Corruption and anti-corruption in environmental and resource management" In: Annual Review of Environment and Resources. Vol. 45, No. 1, pp. 305-329.

TITUNINA, Katerina; KIRILENKO, Fedir. 2017. "The fight of the National Police against corruption in Ukraine" In: Pravovyi chasopys Donbasu. Vol. 2, pp. 152-160.

TRANSPARENCY INTERNATIONAL UKRAINE. 2018. Corruption Perceptions Index 2018. Available online. In: https://ti-ukraine.org/ en/research/corruption-perceptions-index-2018/. Consultation date: 06/12/2020.

TRANSPARENCY INTERNATIONAL UKRAINE. 2019. Corruption Perceptions Index 2019. Available online. In: http://cpi.ti-ukraine. org/\#/. Consultation date: 06/12/2020.

TRUNTSEVSKIY, Yuriy; OLLIV'EN, Margaret. 2017. "Petty" corruption in France: The concept and the methods of social control" In: Journal of Foreign Legislation and Comparative Law. Vol. 3, No. 4, pp. 125-130.

VERKHOVNA RADA OF UKRAINE. 2014. On Prevention of Corruption. Available online. In: https://zakon.rada.gov.ua/laws/show/170018\#Text. Consultation date: 06/12/2020.

VERKHOVNA RADA OF UKRAINE. 2015. On the National Police. Available online. In: https://zakon.rada.gov.ua/laws/show/580-19\#Text. Consultation date: 06/12/2020. 


\section{CUESTIONES POLÍTICAS}

Vol. 39 N $^{\circ} 69$ (Julio - Diciembre 2021): 735-755

YAKHONTOVA, Olesya; YAKHONTOV, Roman. 2020. "On the importance of criminological monitoring in the media" In: Vestnik of St. Petersburg University of the Ministry of Internal Affairs of Russia. Vol. 2, No. 86, pp. 137-142.

ZHUKOVSKA, Liudmyla. 2018. "Powers of specially authorized entities in the field of anti-corruption in Ukraine" In: Pidpryiemnytstvo, hospodarstvo i pravo. Vol. 11, pp. 81-85. 

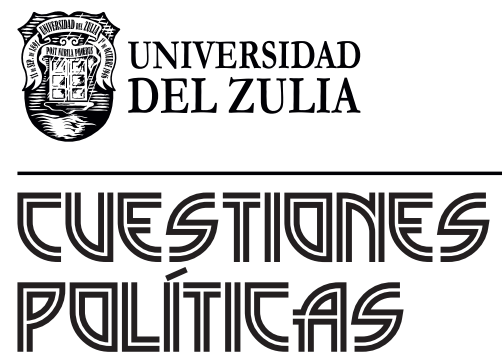

Vol.39 No 69

Esta revista fue editada en formato digital y publicada en julio de 2021, por el Fondo Editorial Serbiluz, Universidad del Zulia. Maracaibo-Venezuela 